\title{
A Conceptual Framework for Islamic Institutional and Retail Investment in Maritime Assets
}

\author{
Adam Abdullah ${ }^{1}$, Rusni $\operatorname{Hassan}^{1}$, Salina Kassim ${ }^{1}$ \\ ${ }^{1}$ IIUM Institute of Islamic Banking and Finance (IIiBF), International Islamic University Malaysia (IIUM), Jalan \\ Gombak, 53100 Kuala Lumpur, Malaysia
}

Correspondence: Adam Abdullah, IIUM Institute of Islamic Banking and Finance, International Islamic University Malaysia, Jalan Gombak, 53100 Kuala Lumpur, Malaysia.

Received: December 26, 2017

doi:10.5539/ibr.v11n2p176
Accepted: January 11, 2018

Online Published: January 18, 2018

URL: https://doi.org/10.5539/ibr.v11n2p176

\begin{abstract}
The purpose of this research is to provide a conceptual framework for Islamic institutional and retail investment in maritime assets. Our objectives are to provide an introduction to seaborne trade and analyze trends in institutional interest in alternative assets and international shipping as well as highlight Islamic and conventional equity structures for institutional and retail investors. Our findings reveal that an Islamic private equity framework involving an unlevered, tax-free investment in maritime assets provides a real alternative to conventional lending and even successful tax-efficient conventional equity structures, since they are not entirely without issues given the significant presence of debt financing from maritime banks. There is a demand for alternative sources of finance, such that Islamic equity finance, rather than conventional lending or structured debt can develop international shipping involving Islamic institutional and retail investment in maritime assets.
\end{abstract}

Keywords: Islamic finance, investment, international shipping

\section{Introduction}

Seaborne trade is fundamental to globalization: $84 \%$ of global trade, representing 11,128 million tonnes, is carried by international shipping totaling 1.75 Bn DWT, $87 \%$ of which, is carried by the primary shipping segments involving are bulkers (43\%), tankers (31\%) and containerships (13\%): however, $75 \%$ of ship-finance is financed on a conventional basis and Malaysian Islamic financial institutions (IFIs) and investors have essentially no exposure to international ship-financing (Abdullah, 2016). In order to determine the willingness and ability to finance maritime assets, investors must understand the associated risks and rewards with regard to international shipping associated with equity structures, as an alternative to risk-free debt finance. In order to facilitate an understanding of international shipping, we begin with an overview of the importance of global seaborne trade and identifying the primary shipping segments involving bulkers, tankers and containerships (section 2). We also analyzed trends in institutional interest in alternative assets and shipping (section 3). We then identify a suitable investment framework for Islamic private equity institutional investors (section 4) and for retail investors involving Islamic finance institutions (section 5). We have also analyzed successful precedents with regard to tax-efficient equity investments in Norway (section 6) and in Germany (section 7). Finally, we provide some concluding remarks and recommendations (section 8).

\section{Overview of Seaborne Trade}

Essentially, growth fundamentals drive shipping investment returns. On average, since 2009 (post financial crisis) approximately $84.5 \%$ of global trade is carried by the international shipping industry (table 1), with 2016 maintaining a constant trend at $84 \%$, representing 11,128 million tonnes (table 1, figure 1), although the forecast for growth in 2017 is expected to soften slightly to $2 \%$ year-on-year (figure 1 ). 


\title{
Growth in Global Seaborne Trade
}

$y$-on-y \% growth in trade, Mn Tns (MTs)

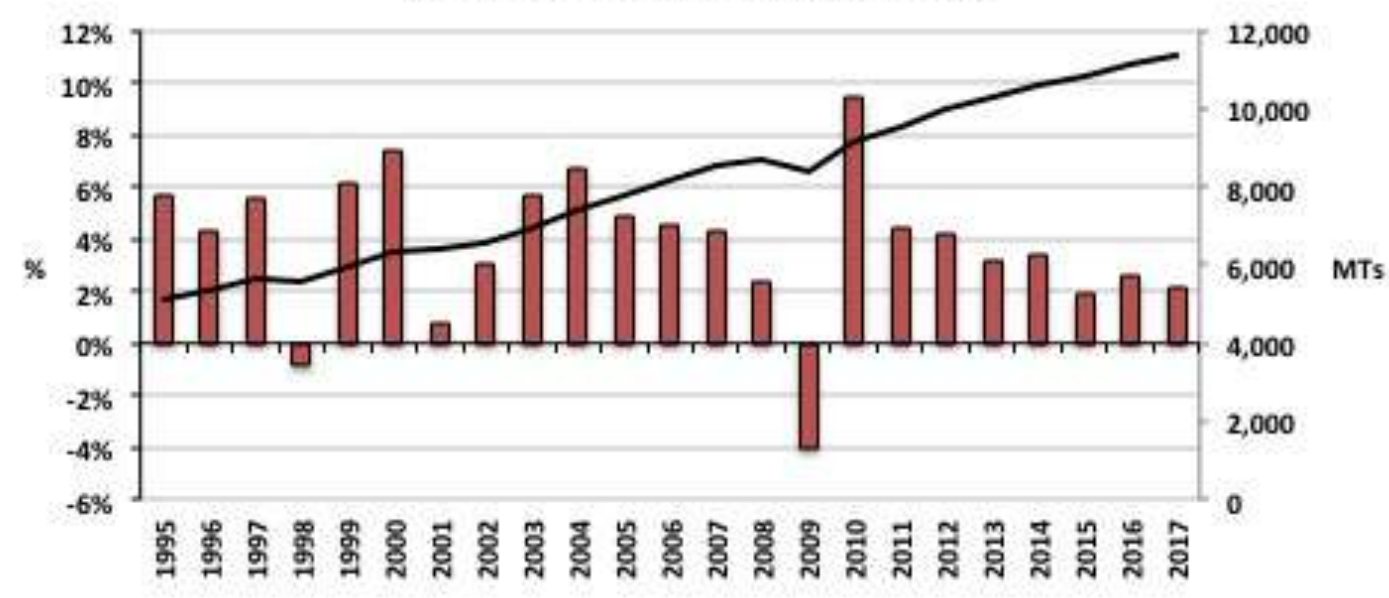

\author{
$\square$ Seaborne Trade Growth (\%) - Seaborne Trade (MTs) \\ Source: Clarksons
}

Figure 1. Global Seaborne Trade and Growth, 1995-2017

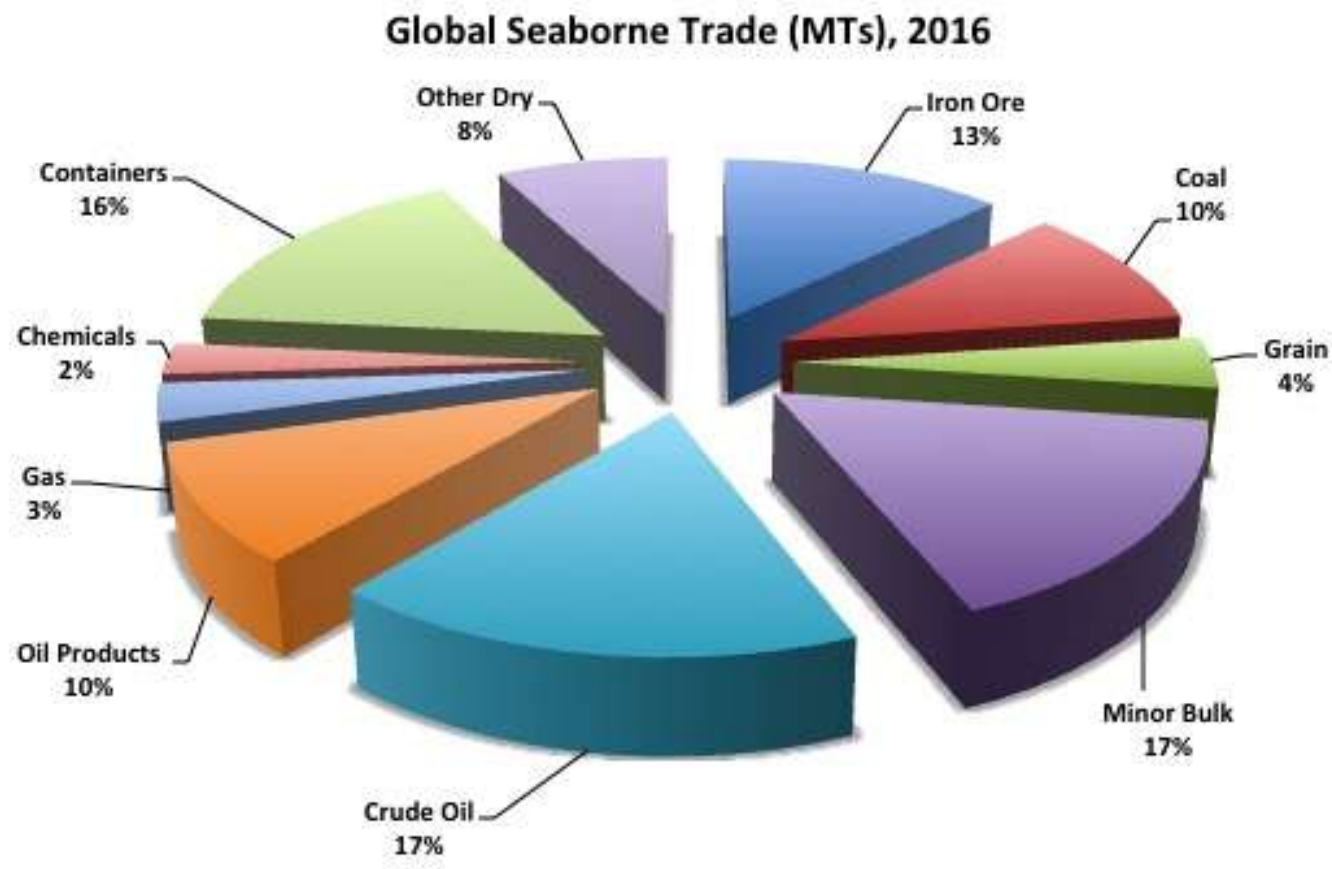

Source: Clarksons

Figure 2. Composition of Global Seaborne Trade, 2016

In any case, globalization could not succeed without the development of the maritime industry, transporting goods on the scale necessary for the modern world. Energy, electricity and steel production underpin industrial development, hence the primary need for oil, coal and iron ore (figure 2) within the composition and patterns of seaborne trade (figure 3 ). 


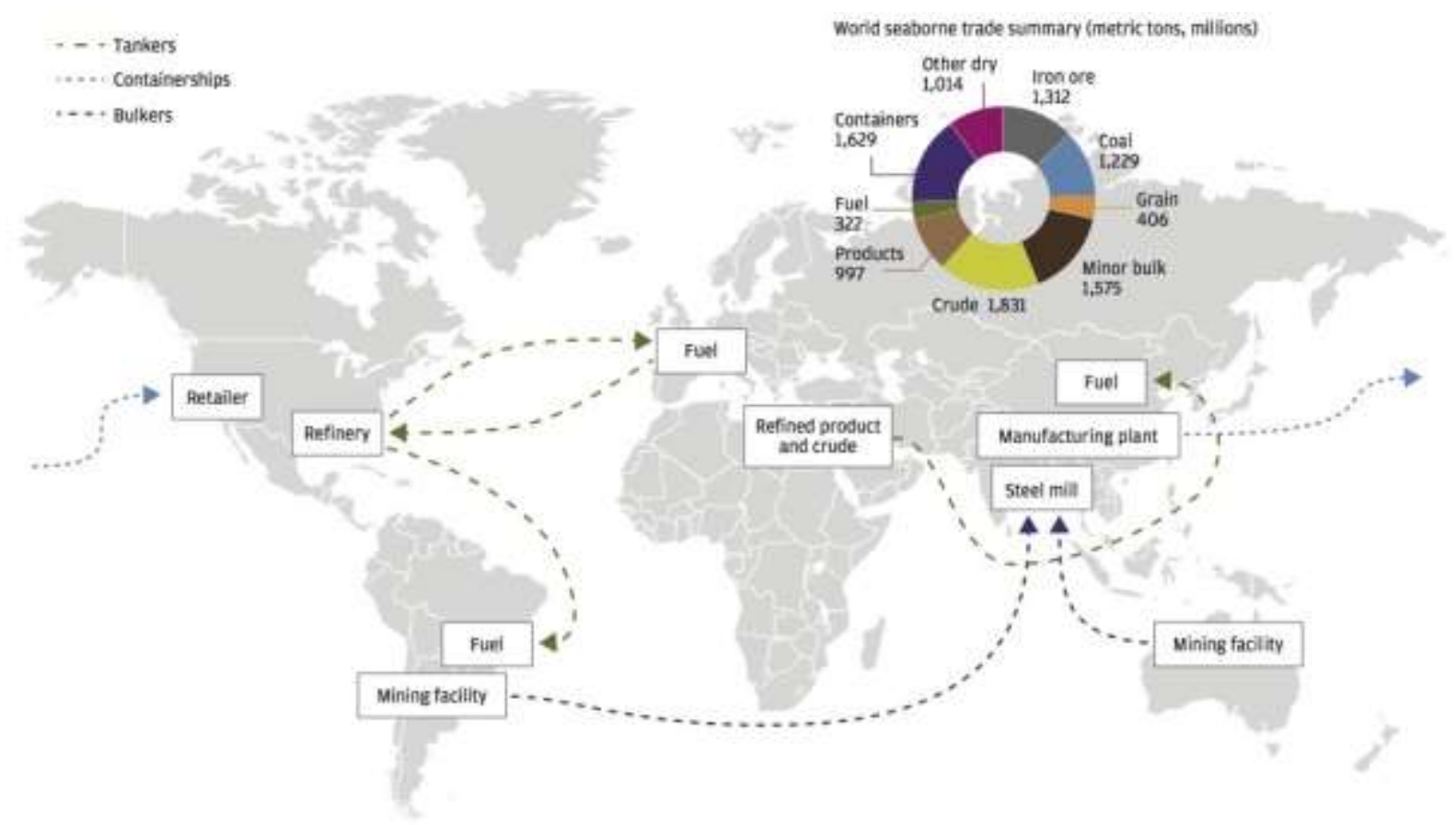

Sources: J.P. Morgan (2015), Clarksons

Figure 3. World Seaborne Trade

The global population already exceeded 7.0 billion in 2011 (table 1) and reached about 7.5 billion by 2016 . Given that world seaborne trade grew to $11.1 \mathrm{Bn}$ tones by then, international shipping is carrying 1.5 tonnes on average for every person in the world today, a trend that has been steadily increasing over the years. Typically, OECD industrial production is a leading indicator to global GDP and also the IMF forecasts a $3.4 \%$ growth for 2017 coupled with a firmer trend towards 2021 (figure 4).

Table 1. Global Seaborne Trade and Analysis

\begin{tabular}{lcccccccc}
\hline Seaborne Trade per Capita & $\mathbf{2 0 0 9}$ & $\mathbf{2 0 1 0}$ & $\mathbf{2 0 1 1}$ & $\mathbf{2 0 1 2}$ & $\mathbf{2 0 1 3}$ & $\mathbf{2 0 1 4}$ & $\mathbf{2 0 1 5}$ & $\mathbf{2 0 1 6}$ \\
\hline World Seaborne Trade (Mn Ts) & 8,355 & 9,148 & 9,554 & 9,946 & 10,286 & 10,637 & 10,841 & 11,128 \\
World Population (Mn people) & 6,846 & 6,930 & 7,013 & 7,098 & 7,182 & 7,266 & 7,349 & 7,428 \\
Trade, Tonnes per Capita & 1.22 & 1.32 & 1.36 & 1.40 & 1.43 & 1.46 & 1.48 & 1.50 \\
Bulk Trade Tonnes per Capita & 0.89 & 0.95 & 0.98 & 1.01 & 1.03 & 1.04 & 1.05 & 1.06 \\
Container Trade per Capita & 0.17 & 0.19 & 0.20 & 0.21 & 0.22 & 0.23 & 0.23 & 0.24 \\
\hline Seaborne Trade Multipliers & & & & & & & & \\
World Seaborne Trade Growth & $-4.00 \%$ & $9.48 \%$ & $4.45 \%$ & $4.09 \%$ & $3.43 \%$ & $3.39 \%$ & $1.93 \%$ & $2.65 \%$ \\
World GDP Growth & $0.00 \%$ & $5.40 \%$ & $4.20 \%$ & $3.50 \%$ & $3.30 \%$ & $3.40 \%$ & $3.10 \%$ & $3.10 \%$ \\
Seaborne Trade/GDP Multiplier & - & 1.76 & 1.06 & 1.17 & 1.04 & 1.00 & 0.62 & 0.85 \\
\hline Industrial Production Growth & $-13.3 \%$ & $8.0 \%$ & $2.4 \%$ & $-0.1 \%$ & $0.4 \%$ & $2.0 \%$ & $0.7 \%$ & $0.2 \%$ \\
Seaborne Trade/IP Multiplier & 0.30 & 1.18 & 1.85 & -40.92 & 8.57 & 1.70 & 2.75 & 13.24 \\
\hline Trade (billion tonnes) & & & & & & & & \\
World Seaborne Trade & 8.36 & 9.15 & 9.55 & 9.95 & 10.29 & 10.64 & 10.84 & 11.13 \\
World Total Trade (all modes) & 9.56 & 10.82 & 11.54 & 11.83 & 12.19 & 12.58 & 12.88 & 13.18 \\
Seaborne Trade as \% of Total & $87 \%$ & $85 \%$ & $83 \%$ & $84 \%$ & $84 \%$ & $85 \%$ & $84 \%$ & $84 \%$ \\
\hline Source: Clarks
\end{tabular}




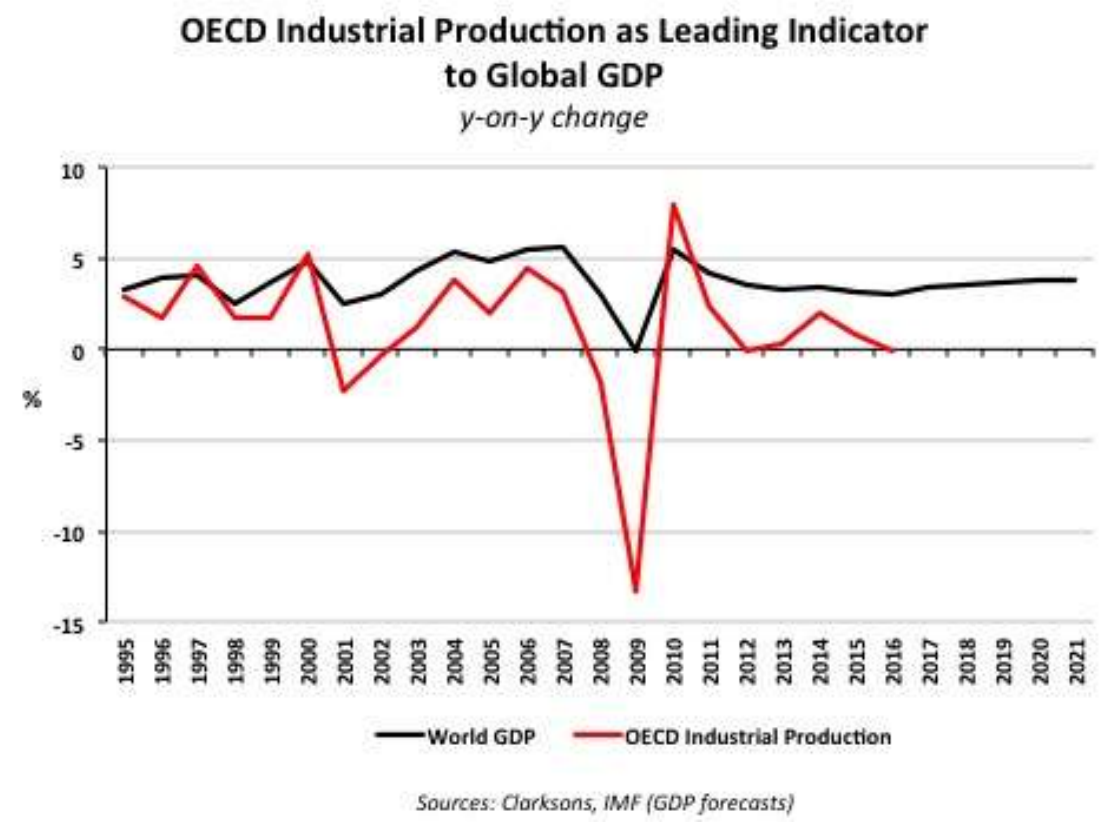

Figure 4. OECD Industrial Production as Leading Indicator to Global GDP

Thus international shipping carries goods for industrial production and finished products for the consumer in an increasingly urbanized world. In terms of economic outlook (market demand), shipping is a growth industry and reflected in the three primary shipping segments (market supply), as ratio of the overall size of the world fleet (1.75 Bn DWT), involving bulkers (43\%), tankers (31\%) and containerships (13\%), totaling 87\% (figure 5).

\section{World Fleet by Tonnage (2015)}

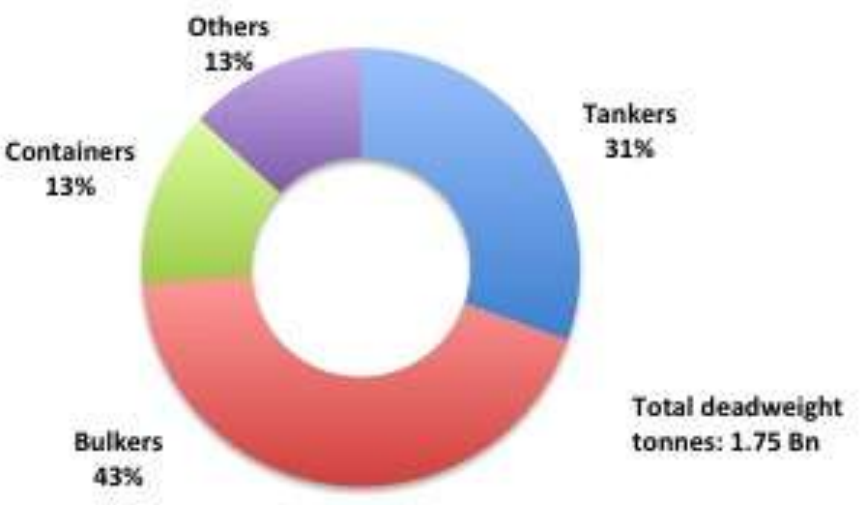

Source: Clarksons

Figure 5. World Fleet in Deadweight Tonnes (2015)

\section{Institutional Interest in Al ternative Assets and Shipping}

With capital market expectations and returns yielding close to zero (U.S.) or even negative (EU and Japan), coupled with domestic liquidity constraints for larger Pension and Investment (P\&I) funds, the switch from financial assets to real assets has been evident in recent years. In terms of asset allocation, by 2013, the value of global alternative assets was UD 7.9 Tn, of which PE was USD 3.6 Tn: since 2013, PE firms have raised USD $500 \mathrm{Bn}$ annually, with USD 1.3 Tn of uninvested commitments totaling USD 1.3Tn (Peqin, 2015; Bain \& Co., 2016). U.S. and European family offices maintain the highest current allocation (26.2\%) as a percentage of their total assets when compared to other investor types (figure 6). Banking regulations do not inhibit them given that they have fewer restrictions and more flexibility with their investment decisions than other investor types, making them attractive to GPs. 


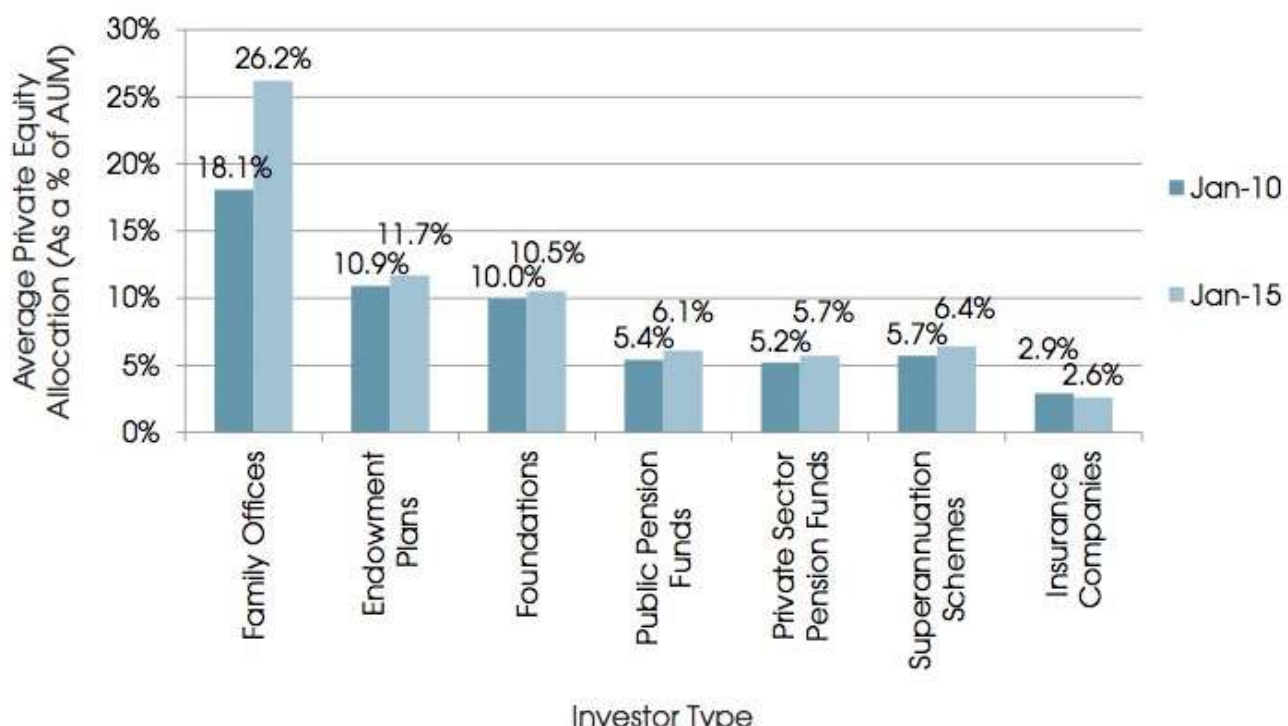

Source: Peqin (2015)

Figure 6. Allocation to PE by Investor Type (As a Proportion of AUM), 2010 vs. 2015

However, even conservative foundation and pension funds are increasing asset allocations to alternative assets generally and PE fund specifically. Of the 16 major national pension markets (P16), whist total USD 36,119 Bn in pension assets and account for $84.4 \%$ of GDP of their economies, seven of the largest pension markets (P7) represent $33.769 \mathrm{Tn}$, or $93.5 \%$, of the P16 markets (table 2). Malaysia is comprised largely of EPF (public pension fund) and also KWAP (Government pension fund).

Table 2. Global Pension Assets

\begin{tabular}{ccc}
\hline Country & $\begin{array}{c}\text { Total Assets 2014 } \\
\text { (USD billion) }\end{array}$ & $\begin{array}{c}\text { \% GDP } \\
\text { (in USD billion) }\end{array}$ \\
\hline Australi** & 1,675 & $113.0 \%$ \\
Brazil & 268 & $12.0 \%$ \\
Canada* & 1,526 & $85.1 \%$ \\
France & 171 & $5.9 \%$ \\
Germany & 520 & $13.6 \%$ \\
Hong Kong & 120 & $41.2 \%$ \\
Ireland & 132 & $53.7 \%$ \\
Japan* & 2,862 & $60.0 \%$ \\
Malaysia & 205 & $60.7 \%$ \\
Mexico & 190 & $14.6 \%$ \\
Netherlands* & 1,457 & $165.5 \%$ \\
South Africa & 234 & $68.6 \%$ \\
South Korea & 511 & $35.3 \%$ \\
Switzerland* & 823 & $121.2 \%$ \\
UK* & 3,309 & $116.2 \%$ \\
US* & 22,117 & $127.0 \%$ \\
Total & 36,119 & $84.4 \%$ \\
\hline Note: $*$ P7 pension national pension market & &
\end{tabular}

Source: Willis Towers Watson (2015)

Since 1995, P7 asset allocations in bonds, equities and cash have reduced (figure 7), while other alternative asset allocations have increased from 5\% to 25\% (Willis Towers Watson, 2015, p.26). In 2013, the top 100 alternative asset managers, ranked by AuM, managed USD 3.27 trillion for their investors (Willis Towers Watson, 2014, p.2). Pension Funds are the largest investors in alternative assets (33\%), or USD $1.088 \mathrm{Tn}$ (Willis Towers Watson, 2014, p.16). 


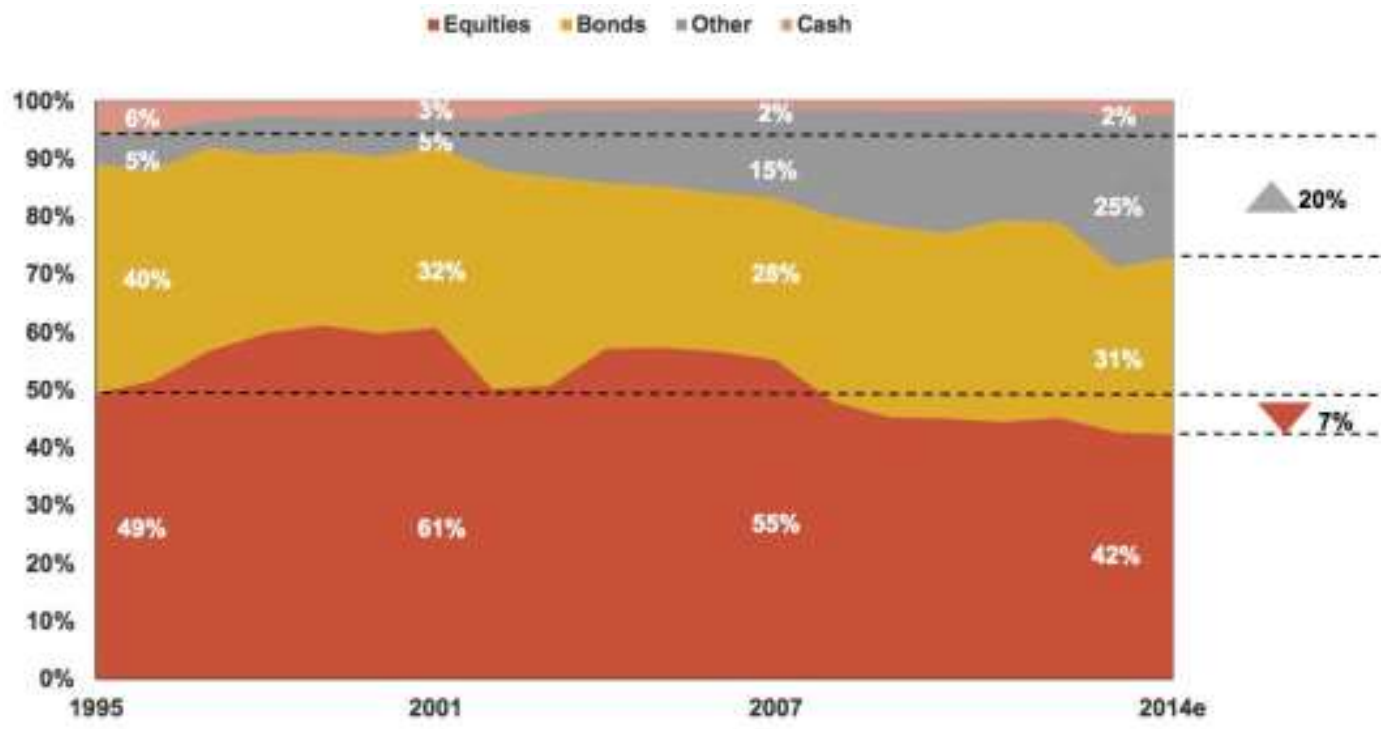

Source: Willis Towers Watson (2015, p.26)

Figure 7. Aggregate P7 Asset Allocation (1995-2014)

Post global financial crisis, a number of hedge funds, private equity firms, HNWIs and P\&I funds have increasingly become investors in shipping (Steeman, 2013). P\&I funds generally look for stable cash-flows, HNWIs seek additional growth opportunites and diversifition, whilst conventional hedge fund and private equity (PE) firms are willing to invest in all aspects of the capital structure. According to Marine Money data, from 2008-2014, PE firms invested a total of about USD 19.2 Bn (figure 8). Generally, PE are making direct investments through common and preferred equity, as well as acquisitions, joint ventures, mezzanine and subordinated debt financing, bridge financing, sale-and-leaseback transactions, and acquisition of distressed shipping debt, often followed by enforcement or restructuring. In 2013 alone, PE invested in about USD 7.1 Bn of maritime assets, of which USD 3.1 bn was in maritime debt (Imhof, 2014) an increasing feature of conventional PE investment in shipping since 2012.

\section{Private Equity Investment in Shipping}

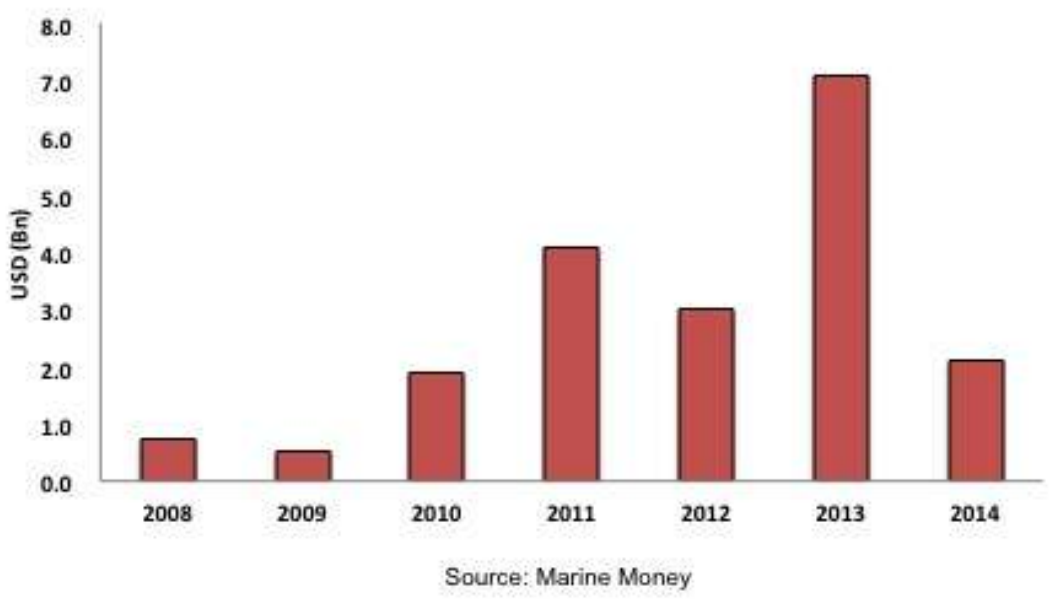

Source: Imhof $(2014, p .4)$

Figure 8. Global Private Equity Investment in Shipping

Specifically, in 2010 Omaha School Employees Retirement Fund invested USD 25 Mn in J.P. Morgan's USD 750 Mn private equity Global Maritime Investment Fund (J.P Morgan, 2010, 2014). In 2011 Ontario Municipal Employees Retirement System (OMERS) concluded a direct acquisition of a shipping services company, V-Group, for USD $520 \mathrm{Mn}$, and also in 2013 Ontario Teachers Pension Plan (OTPP) concluded a direct 
investment in a USD $470 \mathrm{Mn}$ container-leasing acquisition of SeaCube. As one of the largest pension funds in the world, Malaysia's EPF is confronted with domestic liquidity constraints: "Venturing into global markets is part of the EPF's overall risk and return diversification strategy. Our fund size has continuously grown at an average of $10 \%$ and $11 \%$ annually, outpacing Malaysia's Gross Domestic Product (GDP) annual growth of $4 \%$ to $6 \%$. As a result, funds as large as ours are constrained by the domestic market's liquidity making it imperative for the EPF to invest globally" (EPF, 2014, p.28). In reality, EPF is not so much a Malaysian public pension fund, but an international fund manager, whose beneficiaries are primarily Malaysian. By 2015, EPF funds have grown to RM 684.53 Bn and earned a ROI of 7.48\% (EPF, 2015, p.55). With its new Shari'ah compliant savings fund launched in 2016, EPF and indeed other Malaysian pension and investment institutions, should consider Islamic private equity shipping funds as part of their investment committee's diversified asset allocation parametres.

\section{Islamic Private Equity Shipping Fund and Institutional Investment}

Given conventional private equity (PE) expectations, investee portfolio companies would be structured involving 50\%-70\% debt (Stowell, 2013, p.321; Hamzah, 2011, p.26), thus IFIs could also contribute with i-financing of individual SPVs (figure 9) through BBA or bai' bithaman ajil (based on bai' al- 'inah), commodity murabaha (tawarruq), murabaha asset financing, declining co-ownership partnership (musharakah mutanikisah) or even financial leases in the form of ijarah wa iqtina. However, by emphasizing economic substance over legal form (Majallah, 2001, no.3), all of these products, as practiced by IFIs, are devoid of market risk (Abdullah, 2016). Indeed, structured Islamic leases as reflected in Asian Finance Banks's Safeena shipping fund, which initially posted a net yield of $10.2 \%$ p.a. (Tradewinds, 2009). Safeena was a 10-year closed-end fund domiciled in Labuan and was used to acquire a chemical tanker for Berlian Laju Tankers (BLT). As with conventional ship-finance, the lack of embedded market risk ensured that BLT and other shipowners either defaulted or had to re-structure their poorly timed vessel acquisitions, under the weight of their debt obligations in the presence of volatile shipping earnings post financial crisis. The marginal efficiency of capital demonstrates that equity finance and profit-sharing is more efficient than debt finance at the TVM in growing an economy and the normative theory of profit in Islam affirms the necessity to incorporate market risk in Islamic financial transactions (Abdullah, 2016; Abdullah, 2017). The global financial crisis has highlighted precisely this in terms of risk, liquidity and capital considerations.

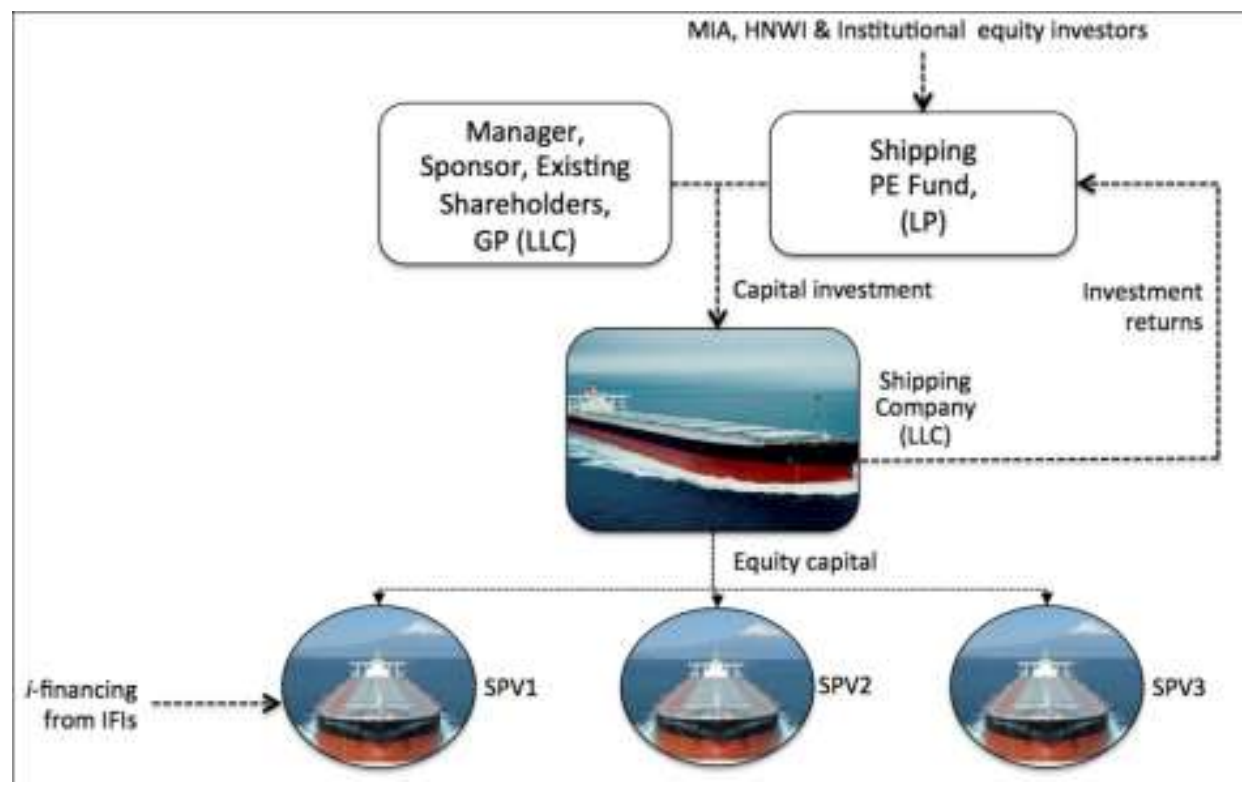

Source: Adapted from Abu Osman (2009)

Figure 9. Islamic Shipping Fund Structure

Another option would be institutional equity investment by IFI Asset Management divisions as LPs, although it is unlikely that they would consider the role of a GP or LP anchor investor given bank risk, liquidity and capital restrictions. Other than HNWIs, potential Shari'ah-compliant equity investors would include institutional investors such as Takaful companies, sovereign wealth funds, endowment funds, as well as public and government pension funds. From a Malaysian perspective, this would include primarily Permodalan Nasional Berhad (PNB), the Malaysian Hajj Fund (Lembaga Tabung Haji, LTH), Khazanah, EPF (KWSP) and KWAP, 
some of whom already have experience with shipping. The main shareholder of MISC is Petronas; the Ministry of Finance, through the Development Bank and Global Maritime Ventures (GMV), owns 18\% of Malaysian Bulk Carriers (MBC); Perbadanan Nasional Berhad (Pernas) formerly owned PNSL (now owned by Konsortium Logistik Berhad, a DLB-Hicom company); and LTH has a joint venture with Alam Maritim. Since 2015, due to a weaker exchange rate, BNM has restricted large-scale investments to be denominated in RM and multi-currency options are possible in shipping.

\section{Islamic Financial Institutions and Investment Account Retail Participation}

The Hanafi jurists, such as Sarakhsi, have observed that "mudharabah under mudharabah is legitimate" (Sidiqqi, 1987, p.59), as do the Malikis and the Shafi'is with the permission of the capital provider ( $r a b b$ al-mal), but the Hanbalis dis-allow any profit to the first mudharib, whom they argue is not performing any business activity. However, this ignores important business decisions. Thus, the majority opinion of the jurists should prevail, in particular that of the Hanafis, since in considering important commercial decisions, or indeed whatever business effort is contributed by the second mudharib, then it is done so on behalf of the fist mudharib (Sidiqqi, 1987, pp.59-62). Accordingly, this ruling has also been applied to the two-tier mudharabah structure of IFIs (figure $10)$.

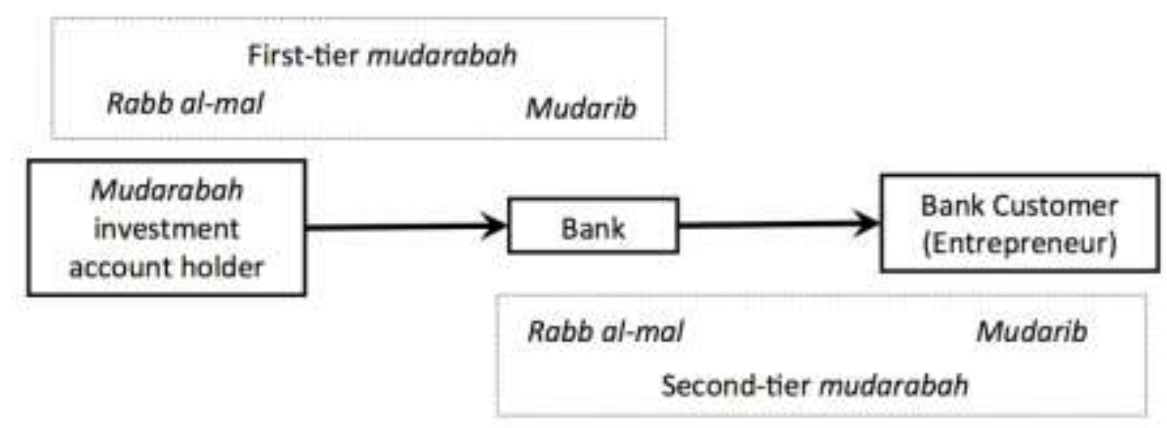

Figure 10. IFI Two-Tier Mudharabah Structure

Equally, this two-tier equity transaction could be conducted through the Investment Account Platform (IAP, 2016), which was launched in 2016. The IAP is owned by 6 IFIs and designed to market IFI investment acco unts and investee projects. This mechanism is similar to the KG system in Germany and the KS system of Norway, which mobilized a considerable amount of savings for maritime investments and converted these countries into maritime nations. However, the current practice by IFIs is to mobilize investment account holders (IAH) with equity savings from retail investors and given suitable product disclosure, funds would be channeled into projects that have been credit evaluated by the IFIs, and in the case of the IAP, by the Rating Agency of Malaysia (IAP, 2016).

The mechanics of this financial intermediation is that equity capital is mobilized through the IAH via the IFIs, or through the IAP. Investees are then financed by debt transactions at profit rates that reflect the time value of money (TVM): hence, the reason for credit analysis by the IFIs or RAM and not investment analysis, if the investees were finance by equity and profit-sharing. Current ROI are about $4 \%$ on the IAH, and the financing returns are about $6 \%$ on the investee projects. The banks themselves publish returns on equity (ROE) of at least $10 \%$. The returns on debt from investees cap the returns to the IAH. Clearly, this suggests an unsustainable business model, where the investment expectations of a ROI from the IAH are no less that the ROE of the shareholders in the IFIs, given they are both accepting the same market risk. Furthermore, the marginal efficiency of capital reveals that equity finance on the basis of profit-sharing increases GDP as compared to debt finance at the TVM of money, which is interest. Unless the IFIs and the IAP accept equity in and equity out, they are likely to be displaced, diminished and dis-intermediated, in other words, disrupted by other crowd-funding platforms through technological innovations in financial services (FinTech) as a result of changes in consumer behaviour that involves the least disruption, or the most efficient service at the least cost.

Nonetheless, the two-tier mudharabah structure could provide a unique model for IFIs to participate in shipping, since the pass-through benefits of tax-efficient investment, as well as associated risk and returns in international shipping, can be transparently communicated to retail investors. Two successful examples of retail participation in international shipping are the German KG system and the Norwegian KS system, although investments are conducted absent of intermediation and are mobilized through private partnerships. Universal Islamic banks have the advantage of (i) mobilizing funds through retail investment accounts and extending $i$-financing from the 
commercial banks, (ii) by managing shipping funds within the asset management divisions, or (iii) by the securitization of maritime assets through asset-backed sukuk from their investment bank divisions. Whilst securitization offers long-term financing, in shipping, debt finance from commercial banks is very competitively priced and rating agencies are cautious about rating bonds whose cash-flow ultimately depends on the spot market. Ship-owners prefer flexible financing arrangements, but a weakness in the KS and KG systems, from the investors' perspective, is the lack of regulation, in protecting the investors' interests: this would be quite different from the robust regulation and governance required of IFIs in Malaysia. Given higher capital costs and reduced tax incentives, increased competition emerged to KS and KG systems, as an alternative to raising capital with tax efficient advantages, with the floatation of independent ship-leasing companies (such as Seaspan in 2005). In this case, the lessor obtains tax benefits by depreciating maritime assets against profit and some of the benefit is passed on to the lessee in terms of lower time-charter rental payments under a long-term bare-boat charter. Time-charter rates, operating expenses and interest rates can be fixed thus insulating companies from shipping cycles, such that dividends are typically paid to investors through preference shares. Structured leases, securitization and debt-finance are only successful if the asset has been acquired competitively. In the presence of volatile earnings and leveraged balanced sheets, even the largest owners in the world can represent a counter-party risk (for example, the Korean ship-owner, Hanjin, one of world's largest containership operators, filed for bankruptcy in 2016).

\section{Norwegian KS System}

In the late 1980s substantial amounts of partnership capital was raised through the Norwegian KS limited partnership structure (figure 11). It is estimated that half of the Norwegian shipping industry operated through KS companies and between 1987-1989 investors committed equity of USD 3.0 Bn (Stopford, 2009, p.306). The KS was established on a single-ship basis with technical management sub-contracted. The KS consists of two more Norwegian or foreign individuals or legal entities, with one general partner (GP) and at least one or more limited liability partners (LLP). The GP must hold at least $10 \%$ of the KS. Each LLP must make a capital commitment of at least $40 \%$ within 2 years from incorporation, of which $20 \%$ is payable upon incorporation. The provision for uncalled capital is left to the partnership agreement and called only if needed (Oldershausen, 2015, p.102). Typically, $80 \%$ of the purchase price was financed from a bank loan and the remainder of the purchase price and any working capital would be drawn from cash paid-in from committed equity. Initially the KS system was attractive since for tax purposes the committed capital could be depreciated by $25 \%$ on a declining basis although allowable depreciation could not exceed the total capital committed (Stopford, 2009, p.306). However, since the 1990s the tax benefits have been reduced although the speed, flexibility and relatively low cost of structuring a KS partnership, has seen interest revived in recent years. Essentially, the KS can be used as a sale-and-leaseback transaction: a KS special purpose company purchase a vessel from the seller and charters it back to the seller on bareboat charter (Oldershausan, 2015, p.102).

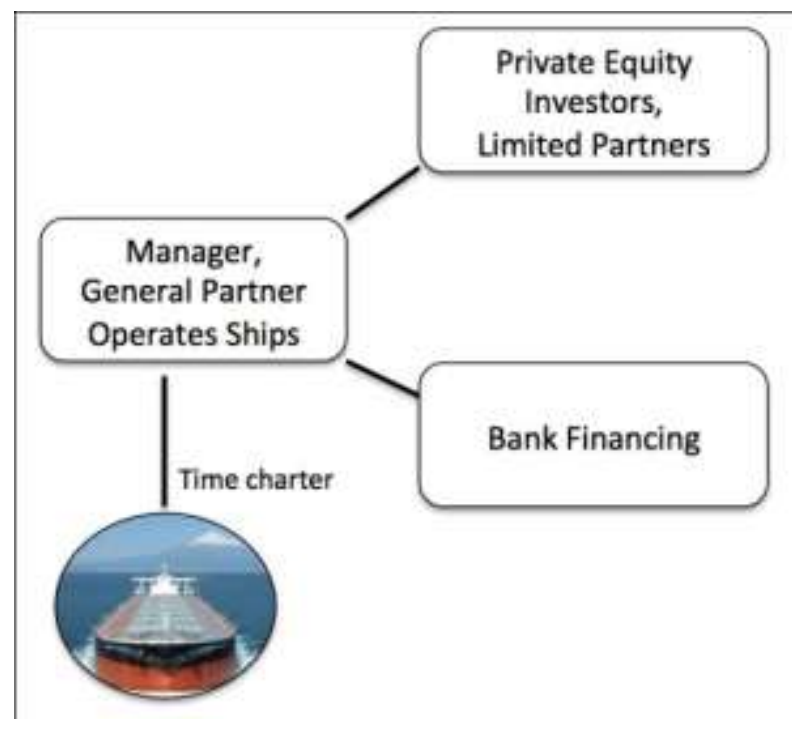

Source: Adapted from Oldershausen (2015, p.106)

Figure 11. KS Shipping Fund Structure 


\section{German KG System}

A form of ship finance that emerged in the mid-1990s, as the equivalent of the Norwegian KS system, was the German registered limited liability partnership, known as the KG shipping fund structure (figure 12). During the 1990s containership companies were generating poor returns and liner operators used KG companies to move vessels off-balance sheet, such that between 1991-2004, liner service operators increased the proportion of chartered-in containerships from $15 \%$ to $50 \%$ and by 2004600 vessels have been financed by KGs, which were typically USD 50-100 million in size. German shipyards were regarded as particularly dominant in the containership market segment and were supported by a strong containership brokerage market in Hamburg. Also Germany had a pool of HNWIs facing high marginal rates of income tax. Moreover, German commercial banks were also expanding their loan book and were willing to extend financing to the tax-efficient KG partnership (Stopford, 2009, p.307), thus providing liner companies with off-balance sheet tax-efficient investments for equity investors and lenders. By the late 1990s, legislators reduced the tax-incentives involving accumulated losses and accelerated depreciation to off-set profitable gains in other investments, such that Germany introduced a tonnage tax in line with other European maritime nations. Whilst it deprived investors of reducing their tax bill, it still gave KG investments a unique advantage over other financial and real assets, such as publicly listed stocks, real estate and cash deposits, which we all liable to standard rates of taxation. Also shipping projects were supposed to attract investors for their profitability not for the loss-making capabilities (Johns and Sturm, 2015, pp.75-76).

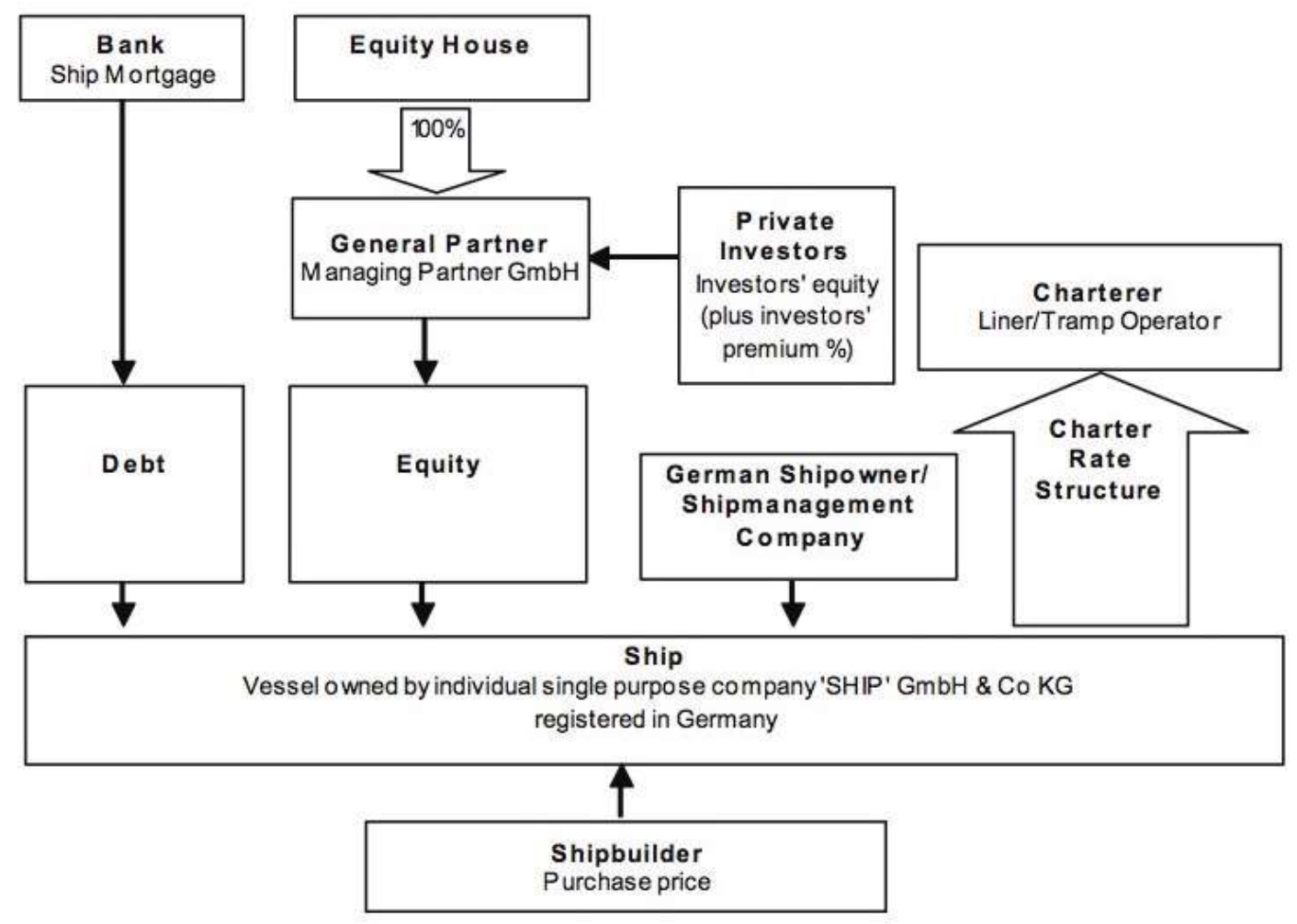

Source: Clarksons (2008, p.7)

Figure 12. KG Shipping Fund Structure

AKG would typically purchase a vessel from the shipyard, or another ship-owner, and obtain a time-charter. The purchase price is obtained from a bank loan with typically a financing ratio of $50 \%$ to $70 \%$, combined with $30 \%$ to $50 \%$ equity raised from German HNWIs and the general manager. The KG finance system is predicated on the simultaneous benefits it yields to private investors and to ship-owners, which allow KG equity houses to provide a profitable service linking the interested parties. Private investors placing equity in KG shipping funds can receive beneficial taxation treatment since the German tax authorities allow funds invested in shipping to be taxed under the tonnage tax system where the amount of tax paid is based on the size of the vessel, as opposed to a profit-orientated tax. Since tonnage tax is the lesser of the two, KG equity houses opt for tonnage tax treatment (Clarksons, 2008, p.3). The effective tax rate is typically $1 \%$ to $3 \%$ of the expected income from trading, such that profits from maritime investments under the scheme are often perceived as "tax-free" (Johns and Sturm, 
2015, p.76). Ship-owners meanwhile benefit from the fact that a portion of the cost of the ship is borne by private investors, which allows ship-owners to place a greater volume of investments than would otherwise be possible.

Accordingly, by 2007, total investment in German closed end funds was estimated to have reached Euro 12.67 Bn, of which an estimated 30\% was in shipping, such that Euro $3.8 \mathrm{Bn}$ of equity was invested in shipping KG funds, which represented a total investment volume in ships of Euro 8.6 Bn. By this time, 64\% of KG financing was in containerships, whilst the remaining was increasing diversified into tankers (especially chemical tankers), bulkers and multi-purpose cargo/container vessels. KG financing has proved to be one of the most successful means of financing ship acquisitions in recent years (Clarksons, 2008, p.3).

\section{Conclusion}

In this paper, we have analyzed the importance of seaborne trade in the context of globalization. We provided an introduction to seaborne trade and have established that $84 \%$ of global trade, representing 11,128 million tonnes, is carried by international shipping totaling $1.75 \mathrm{Bn}$ DWT, $87 \%$ of which, is carried by the primary shipping segments involving are bulkers (43\%), tankers (31\%) and containerships (13\%), such as capesize bulkers, VLCC tankers and panamax containerships (figure 13). However $75 \%$ of ship-finance is financed on a conventional basis. Accordingly, we identified an alternative investment framework for Islamic private equity institutional and for retail investors to participate in international shipping through Islamic financial institutions. Tax-efficient equity finance is not without precedent, given the successful Norwegian KS and German KG structures, but even these involved a significant margin of financing from conventional maritime banks and would only prove successful if assets prices were very low.

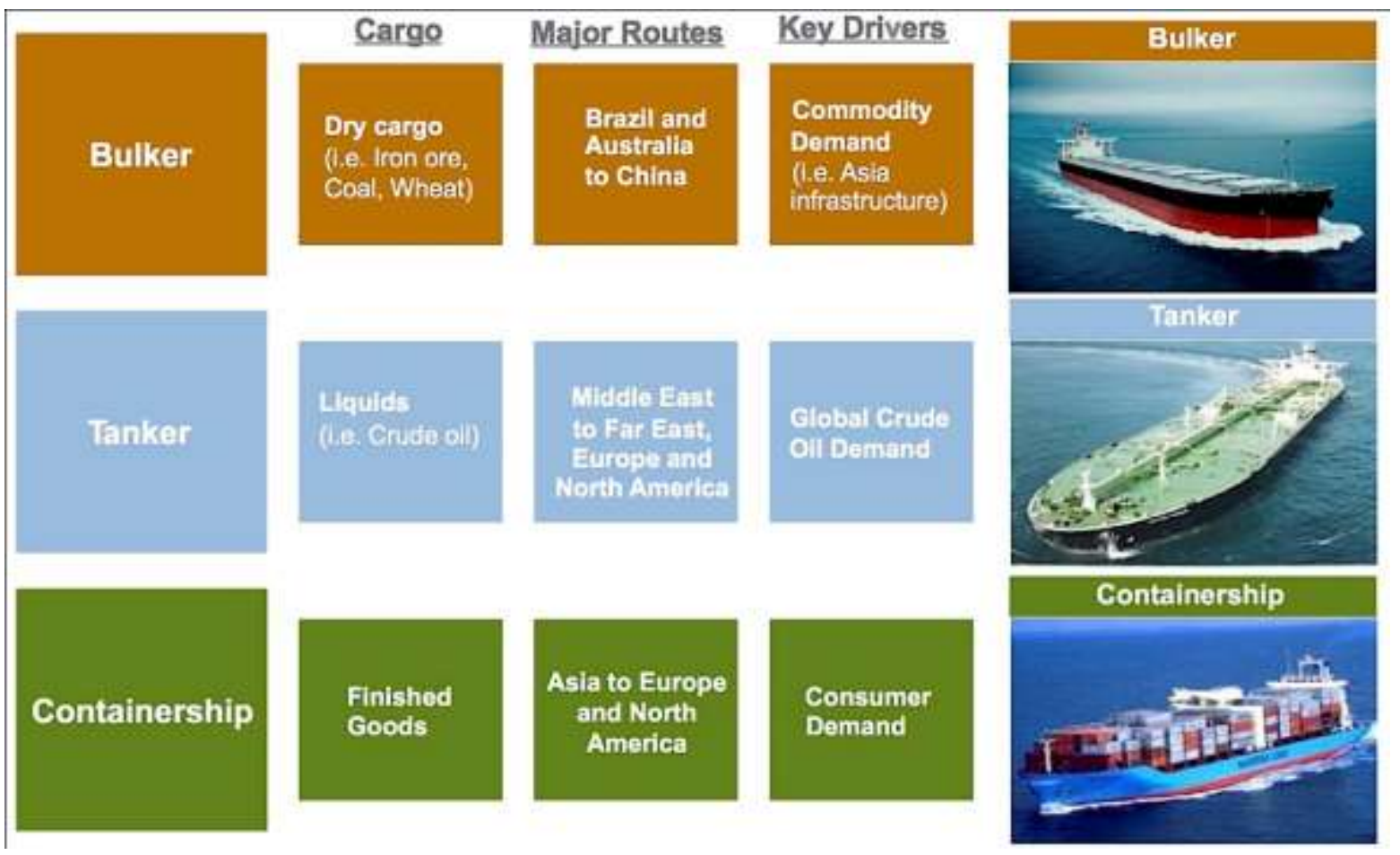

Source: Adapted from J. P. Morgan (2010)

Figure 13. The Primary Vessel Segments in Seaborne Trade

Islamic equity finance in international shipping necessarily involves tax-free and debt-free investment in maritime assets. In fact, there is an array of potential target investments (figure 14) including crude oil tankers, products tankers, chemical tankers, bulk-carriers, liquefied natural gas (LNG) carriers, liquefied petroleum gas (LPG) carriers and containerships with their respective homogeneous vessel types within each segment.

Given exceptionally low asset prices, there is currently an enormous investment opportunity available to retail and institutional investors, with the participation of P\&I institutions as well as IFIs, to participate in Islamic equity finance and investment in the development of international shipping. 


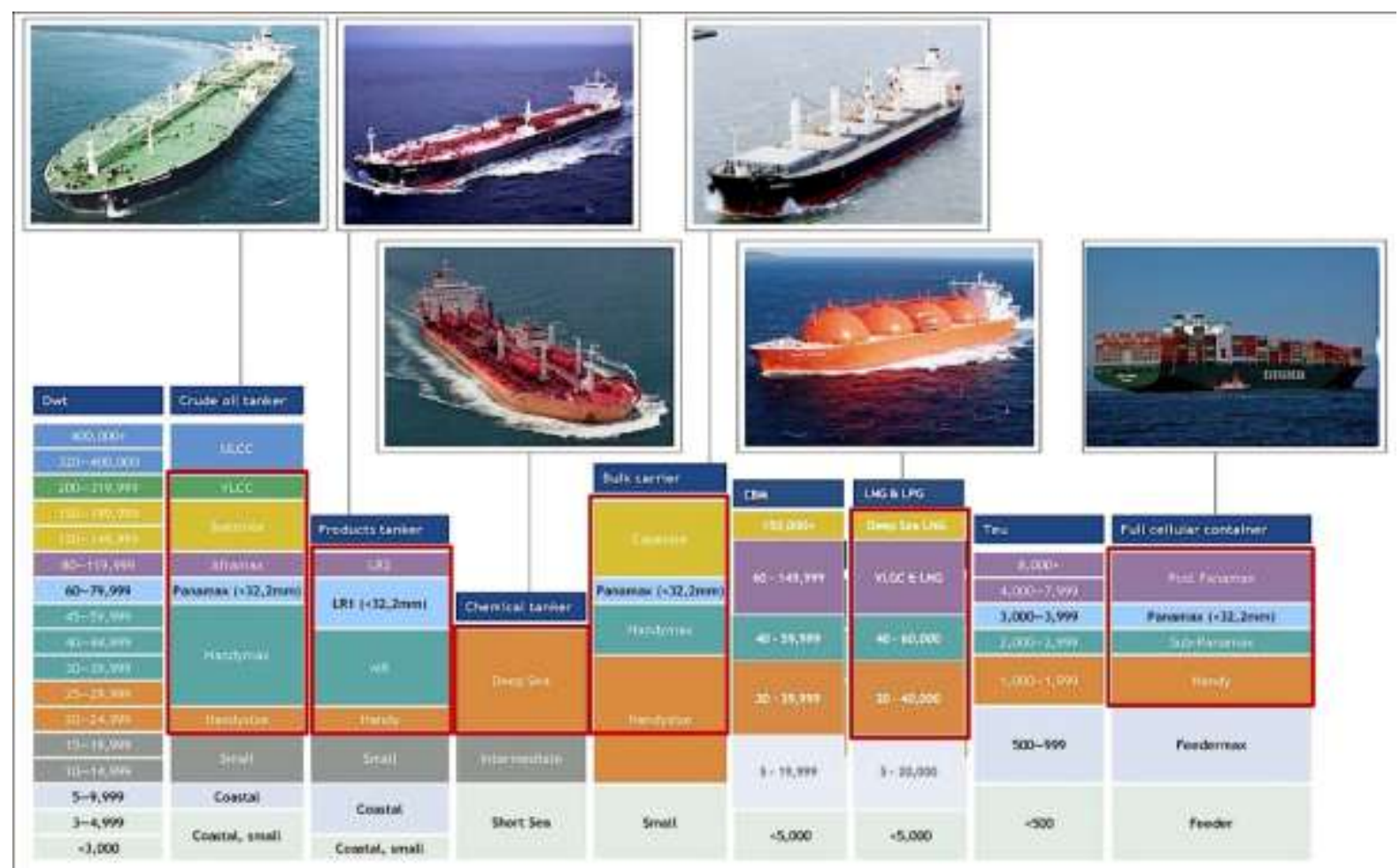

Source: J. P. Morgan (2014)

Figure 14. Target Investments in International Shipping

\section{Acknowledgment}

The authors wish to acknowledge the support of the Ministry of Higher Education (MOHE) of Malaysia, since this research was funded through the FRGS national research grant no. FRGS/1/2016/SS01/UIAM/02/4.

\section{References}

Abdullah, A., Hassan, R., \& Kassim, S. (2016, Dec.). A Conceptual Framework of the Suitability of Islamic Private Equity in International Shipping. Al-Shajarah, Special Issue on Islamic Banking \& Finance, 115-138.

Abdullah, A., Hassan, R., \& Kassim, S. (2017, Jul.). Developing an Islamic Investment Framework for Maritime Assets. The Social Sciences, 12(10).

Abu Osman, A. A. (2009, 20-21 May). Why Islamic VC/PE is Needed and It's Importance. presentation by CMS Opus Private Equity at The 2nd Islamic Venture Capital and Private Equity Conference 2009, Kuala Lumpur Convention Centre.

Clarksons (2016). Shipping Intelligence Network database, Clarksons Research Services, London. Retrieved from https://sin.clarksons.net/

EPF. (2014, 2015). Employees Provident Fund (EPF). Annual Reports. Retrieved from http://www.kwsp.gov.my/portal/en/about-epf/annual-report

Hamzah, Z. (2011). Islamic Private Equity and Venture Capital. Kuala Lumpur: IBFIM

IAP. (2016). Investment Account Platform. Retrieved from https://www.iaplatform.com/

Imhof, J. H. (2014, 12 Nov.). Private Equity and Shipping: What's Been Done So Far. Presentation, at the 15h Annual New York Ship Finance Forum. Retrieved from https://www.marinemoney.com/content/ship-finance-forum

International Monetary Fund (IMF). (2017). International Financial Statistics (IFS). Retrieved from http://www.imf.org/en/Data

Johns, M., \& Sturm, J. (2015). "The German KG System” in HSBA (Hamburg School of Business Administration) Handbook on Ship Finance. Schinas, O. et al (Eds). Heidelberg: Spriner, pp.71-85.

Majallah. (2001). The Mejelle: Being An English Translation of Majallah el-Ahkam-I-Adliya, And A Complete 
Code of Islamic Civil Law, enacted in Imperial Turkey 1869-1876, trans. by Tyser C.R., Demetriades D.G. \& Effendi, I.H. in 1901. Petaling Jaya: The Other Press.

Marine Money. (2009). "Safeena”, Marine Money Offshore. Retrieved from https://www.marinemoneyoffshore.com/node/4530

Morgan, J. P. (2010, 20 May). J.P. Morgan Global Maritime Investment Fund (GMIF). Presentation to San Diego County Employees Retirement Association (SDCERA).

Morgan, J. P. (2014, May). J.P. Morgan GMIF and Market Update. Presentation to Omaha School Employees Retirement System of Douglas Country School District 0001.

Morgan, J. P. (2015, Jan.). "Maritime Investing: An Income Opportunity", Insights and Research, Investment Insights. Retrieved from https://am.jpmorgan.com/nl/institutional/library/maritime-investing

Oldershausen, C. V. (2015). "Other Equity Markets for Shipping" in HSBA (Hamburg School of Business Administration) Handbook on Ship Finance. Schinas, O. et al (Eds). Heidelberg: Spriner, pp.99-108

Preqin. (2015). Global Alternatives Report 2015. Retrieved from https://www.preqin.com/

Siddiqi, M. N. (1987). Partnership and Profit-Sharing in Islamic Law. 1/e (1985), reprinted, Leicester: The Islamic Foundation.

Stopford, M. (2009). Maritime Economics. 3e. London: Routledge. https://doi.org/10.4324/9780203891742

Stowell, D. P. (2013). Investment Banks, Hedge Funds and Private Equity. 1/e (2010), revised 2/e, Oxford: Academic Press (Elsevier).

Tradewinds. (2009, 4 Dec.). Islamic Fund Safeena makes debut with chemical tanker. Retrieved from http://www.tradewindsnews.com/

Willis Towers Watson. (2015). Global Pensions Asset Study 2015. Retrieved from https://www.willistowerswatson.com/en

\section{Copyrights}

Copyright for this article is retained by the author(s), with first publication rights granted to the journal.

This is an open-access article distributed under the terms and conditions of the Creative Commons Attribution license (http://creativecommons.org/licenses/by/4.0/). 